\title{
Interest in STEM Careers of Students from Public High Schools in an Emerging Economy
}

\author{
María Amparo Oliveros Ruiz \\ Eduardo Cabrera Cordoba \\ Roumen Nedev \\ Universidad Politécnica de \\ Baja California, Mexicali, \\ México
}

\author{
Lidia Esther Vargas osuna \\ Benjamín Valdez Salas \\ Michael Schorr Wienner \\ Universidad Autónoma de \\ Baja California, Mexicali, \\ México
}

\author{
Juan Jose Sevilla Garcia \\ Roberto Luis Ibarra Wiley \\ Universidad Autónoma de \\ Baja California, Mexicali, \\ México
}

\begin{abstract}
The importance of Science, Technology, Engineering and Mathematics (STEM) careers and its role in scientific and technological progress, for economic development in the region, promoted the interest of technological dissemination sessions aimed at prospective students at the Polytechnic University of Baja California in the city of Mexicali, Baja California. A group of 2,154 students from 20 different institutions of public high school education answered a survey designed as an evaluation tool for a career path or technology area of interest. The survey results show that students have a low preference for STEM careers. Moreover, these results were augmented with an additional study on the academic interest of students by gender in the city of Mexicali, Baja California, also conducted by the authors. It raises the importance of teaching science in the early education levels, which aims to prepare scientists and technologists needed for the development of research and innovation as a foundation for economic prosperity and welfare of an emerging economy such as Mexico.
\end{abstract}

\section{Introduction}

In most Latin American countries, the teaching of science and technology is intended to be among the priorities of education programs. Mexico has some special points in epistemological and historical reflection in the basic disciplines: mathematics, science, and technology. They focus on deep technical details, but lack a comprehensive and accurate view of the general concept of science and technology, how they perform in today's world, their social impact and relationships, or the history of science and technology [1].

Efforts and budgets have been devoted to improve the policies, curricular, teaching methods, and materials related to scientific disciplines as well as the training of specialized teachers, so they are up to date and interested in their professional mission. In this framework, well-educated teachers will have the natural motivation to teach in early education levels. As a consequence of this social environment, students will choose the fields of science and engineering. In recent decades, the scientific community has expressed great concern about the decrease in the number of male and female students who enroll in scientific and technological branches.

\section{Current Status of Engineering in Mexico}

In Mexico, there is an emerging technology development and misunderstanding towards scientific research, due to the absence of a true culture of science and technology.

There is the need to motivate student's interest in STEM careers and give them the academic tools to identify opportunities for technological development. The level of engineering in Mexico is seen as below that of industrialized countries. There are many schools of engineering, but they suffer, to greater or lesser degree, the lack of resources for development, such as laboratory equipment and highly qualified staff. This is due, in part, to the situation of dependence on technology in our country. Emphasis will be placed on the need to update the plans and study programs in engineering to avoid the lag in the new registered progress [2].

In the state of Baja California, located on the border with the United States, northwestern Mexico, 2,200 engineers graduate from public and private schools each year, but this does not satisfy the demand of the industrial plants in the region. Only $20 \%$ of the college students in the state are enrolled in some type of engineering [3]. In Baja California, there are approximately 1,199 assembly plants that require many engineers [4]. 
In addition to this problem, the Faculties of Engineering are facing a high dropout rate that represents above $50 \%$ [3].

According to the National Development Plan (NPD) 2013-2018, the country's contribution to global knowledge production is less than $1 \%$ of the total; and the number of graduated doctors per million of inhabitants (29.9) is insufficient for attaining the future human capital that the nation requires. International experience shows that it is convenient to invest in scientific research and experimental development at a rate greater than or equal to $1 \%$ of GDP. In Mexico, this figure reached $0.5 \%$ of GDP in 2012, representing the lowest level among the Organization for Economic Cooperation and Development (OECD) countries, and even less than the average for Latin American countries [5].

ANUIES identified, in 2006, a list of problems within the higher education system in Mexico such as: disruption of higher education system compared to previous educational levels, persistence of high dropout rates and low efficiency, and failure and little impact of policies to promote scientific and technological research.

\section{Science, Technology and Society Teaching as a Proposal to Improve Enrollment in STEM Careers}

The movement of Science, Technology, and Society (STS) emerged in the second half of the 20th century due to the convergence of various factors with the objective of a better understanding of the social and organizational dimension of science and technology.

Educational guidance of STS facilitates innovation in the curriculum of science and technology at all levels of education, in accordance with the new goals for science and technology education, and is required for the 21 st century.

The STS is an innovative general education proposal and for its effective implementation, it is necessary to change teaching practice, the role of the teacher, and learning strategies. From the first perspective, it is to understand better the science and technology in its social context, addressing the interrelationship between scientific and technological developments and social processes [6]. It is a radical new approach to the curriculum at all levels of education, in order to provide training and knowledge, especially in values that promote responsible citizenship and democratic participation in the evaluation and control of the social implications of science and technology.

In STS modality, teachers not only have to communicate the objectives to be achieved, but must personally strive to lead by example. The teacher should also promote communication in the classroom, increasing students' activity and autonomy [7].

In traditional training there is a very large gap between the sciences and the humanities. However, in the new knowledge society in which we live, integrity of the individual's professional development is essential to bring all this expertise into an action that impacts the society.

The common denominator of the STS curriculum is to present science and technology integrated together in a social context and focuses on students, not learning units, trying to facilitate the understanding of their experiences and phenomena that occur in everyday life, in ways that school learning is applied in technological and social environment, and provide them democratic participation in decision making on social issues related to science and technology. STS education attempts to balance three types of objectives: knowledge and learning skills for personal or cultural purposes; processes of scientific and technological research; and development of values for professional, public, and political issues, either local or global.

The former allows a better connection between student's interests and the academy, but can lead to a partial and too specialized education due to its more specific nature. The second approach, more general, could provide students with a more comprehensive and durable structure, but it is far more often seen because it treats STS relations from the perspective of other disciplines such as philosophy, ethics, sociology, history, cultural, and economic aesthetic [8]. STS activities may contribute to these changes using the scheme of constructivist teaching-learning process (Figure 1).

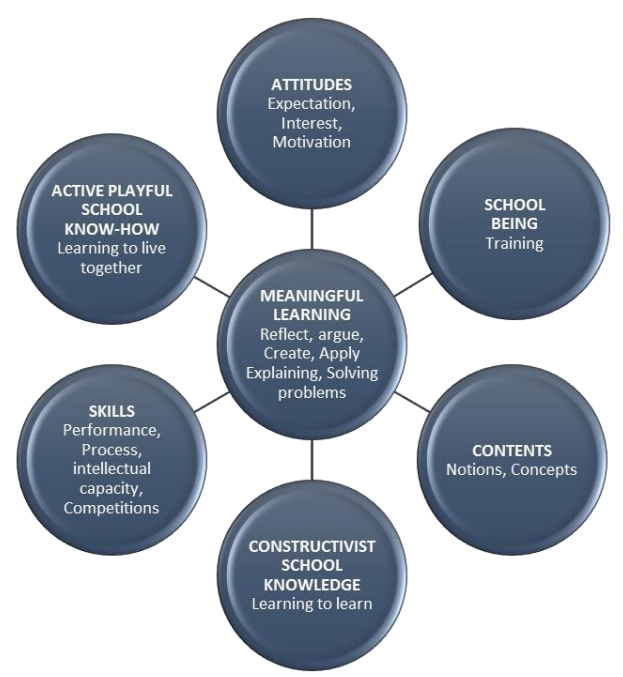

Figure 1. Schematic constructivist teachinglearning process. 
Table 1. STEM career interest of students from higher secondary education

\begin{tabular}{lcc}
\hline Description & No. & $\%$ \\
\hline Total respondents & 2154 & 100 \\
Interested in engineering & 482 & 22 \\
Not Interested in engineering & 1158 & 54 \\
Interested in more than one career & 61 & 3 \\
Omitted to answer & 453 & 21 \\
\hline
\end{tabular}

It is highly recommended to practice collaboration since this set of activities is important to human development. The recommended strategies to be applied include the use of information technology, allowing generation of a dynamic curriculum of science, such as the use of Moodle platform, educational websites, and so forth. Suggested topics for experiential workshops are: industrial water pollution, AIDS-2000: AIDS vaccine, the school network, roads and highways, the management of urban waste, employment or automation.

\section{Method}

During January to April 2012, technological diffusion was held for students graduating from public institutions of higher secondary education. Along with this exercise, an exploratory study was conducted in order to understand the perception that students may have about their vocational preferences after graduating from high school.

The diffusion consisted of a given talk on the importance of engineering as a promoter of scientific and technological progress and the economic development of the region and at the end of the conference, a survey on a career preference, gender, or area of interest was handed over.

\section{Results}

A total of twenty public high schools were covered with a total of 2,154 students registered. When analyzed the surveys it was found that 1,158 of the respondents were not interest in pursuing university studies in any engineering career, while 482 , which is only the 22 percent, demonstrated interest. The rest of the respondents omitted the data or were interested in more than one career (Table 1).

On the other hand, about the academic interest of students by gender, the study revealed that females accounted for $53 \%$ of all students who registered and who are graduating from upper secondary education. From the group that is not interested in any STEM career $65 \%$ are female and $35 \%$ male. Regarding the students who are interested in continuing their studies in some STEM career, $69 \%$ are males and only $31 \%$ females (Figure 2).
As a reference, OECD education indicators from 2012 regarding the percentage of 15-year-old boys and girls planning a career in engineering or computing shows Mexico in third place just below Poland and Slovenia, where girls are $7.8 \%$ and boys $27.3 \%$.

\section{Conclusions and Recommendations}

The results of this exploratory study indicate that there is little interest from the next graduating class of high school students in continuing their studies in the field of some STEM career. It is necessary to offer them a scenario that allows them to deal with various ethical dilemmas they will have to decide. This experiment was reproduced in a learning environment through experiential workshops. As a result, we observed a stimulation of students' reflective and critical attitude on various economic, political, social, and environmental issues. We also observed an attitudinal change brought by the dynamics of collaborative work that allowed them to implement values such as respect, tolerance, and solidarity among others.

Furthermore, it became evident that teachers need to be updated in the teaching of science based on STS. Therefore, informational and planning meetings were held among secondary education level and academic staff of the university. Free access information from the University of California, Berkeley (2012) was used and proved to be a good a source of STS training materials, guides, assessments, practice exercises, recommendations.

With regard to gender equity, there has been a greater presence of women in engineering professions than in previous generational cohorts. The percentage of women interested in engineering careers is low, considering that secondary education graduates are about the same amount of men and women [3].

As shown by other studies, women generally have a better academic performance in high school, and at higher education levels, they show greater motivation, discipline, persistence, and a varied use of learning strategies in careers that have traditionally been considered "unfit" for them [9] [10].

Even now, in most OECD countries, fewer than $30 \%$ of women graduate in the fields of engineering, 


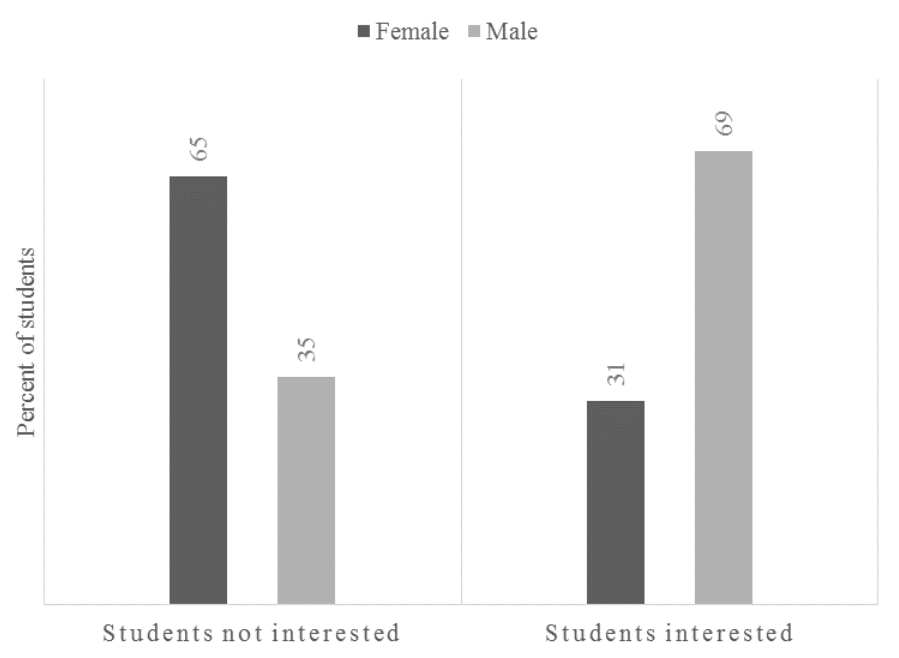

Figure 2. Students by gender interested in a STEM career

manufacturing and construction. Not surprisingly, women are underrepresented in high-technology industries [11].

Hence, the importance of teaching science with an STS model; it is essential to foster of student interest in both genders in matters of science and technology as a priority for economic progress in the region and to promote a better quality of life for citizens.

Finally, we recommend the practice of experiential workshops using information technologies as a strategy for the generating of a dynamic curriculum of science by the discussion of hot topics such as pollution, advances in fighting diseases, infrastructure, genetics, industrial development, nano science, and ethics.

\section{References}

[1] Vázquez, A., Acevedo, J., \& Manassero, M. A., "Más allá de la enseñanza de la ciencia para científicos": hacia una educación científica humanista. Revista Electrónica de la Enseñanza de la Ciencias, 2005. 4(2).

[2] Rivera, M., "El futuro de las Universidades en los Países en Desarrollo", Revista ANUIES, 1990 19(74), pp.1-8.

[3] ANUIES [National Association of Universities and Institutions of Higher Education], Anuario estadístico de educación superior en México 2011-2012, 2011-2012.

[4] Secretaría de desarrollo económico de Baja California. (2014). 'Directorios empresariales', http://www.bajacalifornia.gob.mx (8 Mayo 2014)

[5] Plan Nacional de Desarrollo. 2013-2018. Gobierno de la República Mexicana.

[6] Acevedo, J., Revista de Educación de la Universidad de Granada, 1997, 10, pp. 269-275.
[7] Waks, L. J. (1996). Filosofía de la educación en CTS. Ciclo de responsabilidad y trabajo comunitario. In A. Alonso, I. Ayestarán \& N. Ursúa (Eds.), "Para comprender Ciencia, Tecnología y Sociedad”, Estella: EVD., pp. 19-33.

[8] Aikenhead, G., \& Ogawa, M., "Indigenous knowledge and science revisited". Cultural Studies of Science Education, 2007, 2, pp. 539-620.

[9] Moran, K., Abandono de Estudios en la Facultad de Ingeniería, Campus Mexicali de la UABC. Tesis de Maestría en Ciencias. Instituto de Ingeniería, Universidad Autónoma de Baja California, 2012.

[10] Duarte, M., Sevilla, J., Gutiérrez, S., \& Galaz, J. "Expectativas y capital académico de estudiantes de nuevo ingreso a ingeniería en Mexicali, México: Discusión desde la perspectiva de género", Ingenierías, 14(51), pp.22-30. 2011.

[11] Organization for Economic Cooperation and Development (OECD), (2012) 'Education at a glance', http://www.oecd-ilibrary.org (8 May 2014)

[12] ANUIES [National Association of Universities and Institutions of Higher Education], Consolidación y avance de la educación superior en México, 2006.

[13] OEI, Ciencia, Tecnología, Ingeniería e Innovación para el desarrollo. Madrid Una visión para las Américas en el siglo XXI, 2006.

[14] Plan Nacional de Desarrollo. 2007-2012. Gobierno de la República Mexicana.

[15] UNESCO. (1999) 'Enseñanza de las ciencias y la tecnologia', http://www.unesco.org (5 February, 2014).

[16] University of California, Berkeley (2012). 'Understanding science: How science really works', http://www.oei.es (5 February 2014).

[17] USAID. (2014) 'Encuesta de competencias profesionales 2O14', www.usaid.gov (3 February 2014). 